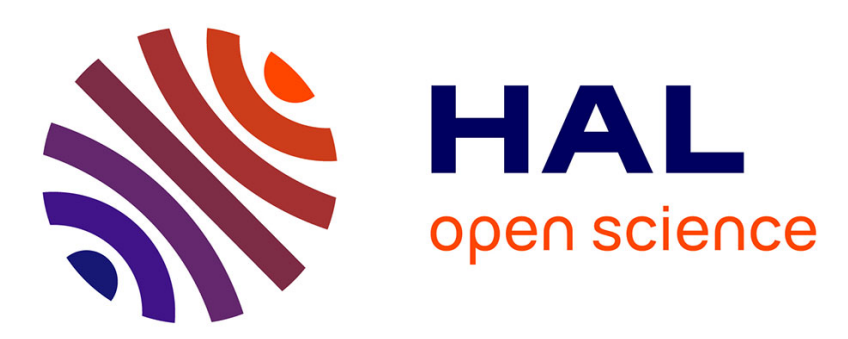

\title{
Evidential markers in French scientific writing: The case of the French verb voir.
}

Francis Grossmann, Agnès Tutin

\section{To cite this version:}

Francis Grossmann, Agnès Tutin. Evidential markers in French scientific writing: The case of the French verb voir.. Linguistic Realization of Evidentiality in European Languages, pp.279-308, 2010, 978-3-11-022396-5. hal-01956607

\section{HAL Id: hal-01956607 https://hal.science/hal-01956607}

Submitted on 16 Dec 2018

HAL is a multi-disciplinary open access archive for the deposit and dissemination of scientific research documents, whether they are published or not. The documents may come from teaching and research institutions in France or abroad, or from public or private research centers.
L'archive ouverte pluridisciplinaire HAL, est destinée au dépôt et à la diffusion de documents scientifiques de niveau recherche, publiés ou non, émanant des établissements d'enseignement et de recherche français ou étrangers, des laboratoires publics ou privés. 
Preliminary version

Francis Grossmann and Agnès Tutin

LIDILEM, Université Stendhal Grenoble 3

\section{Summary}

The present paper describes a study of the evidential functions of the French verb voir/to see in the scientific genre, based on a corpus compiled from writings in the fields of linguistics and economics. Our objective was to answer two questions:

(a) What are the main functions of this marker in this genre and how are these functions made manifest (meaning and use of voir)?

(b) Do different fields have specific ways of using evidential markers?

A brief presentation of the evidential functions of the lexicon of perception is followed by a review of the literature on the evidential meaning of voir. In order to explore this linguistic phenomenon, we compiled a large corpus of scientific writings and annotated the occurrences of voir. This approach enabled us to address the linguistic properties of voir as a statement marker and to analyze its other evidential function, that of a reference marker. We also compared the evidential functions of voir in linguistics and economics writings using a corpus drawn from these two fields.

\section{Evidential Markers in French Scientific Writing: the Case of the French Verb voir}

\section{Introduction}

In evidential typologies, visual evidence ${ }^{1}$ is considered to be one of the prime sources of information. One somewhat paradoxical result of this is that certain languages with evidential systems do not have linguistic markers to indicate visual access to information - the default mode of access - whereas modes such as inference or hearsay are marked linguistically.

Aikhenvald (2004) found that in languages such as French and English that do not possess evidential markers in the strict sense of the word, the notions of evidentiality are sometimes used abusively; that is to say, evidential markers are grammaticalized. Excluding the specific lexicon used in evidentiality research, she did however recognize evidential strategies that are used to add evidential semantic extensions to linguistic tools with other main functions (modal markers, reported speech markers, etc.).

This restrictive vision can be nuanced by arguing that, in the same way that it is useful to study the lexical methods some languages use to express aspect (even if only to observe their interactions with the values of inflectional classes), it may also be interesting to study how these languages mark evidentiality, including through lexical means; especially as languages with evidential systems have often derived these grammatical tools from lexical markers, such as the verbs of perception. A tendency to grammaticalize lexical markers can be seen in the French language's lexicon of visual perception, particularly with respect to the use of $v u /$ seen. As early as the Middle Ages, $v u$ was being used as a preposition with the meaning of eu égard à/considering, and, in the $17^{\text {th }}$ century, $v u$ began to be used in legal documents to signify après avoir examinélafter having examined. In addition, the conjunctive locution $v u$ que/given appeared in the $14^{\text {th }}$ century and it is still used today in some areas. It is true that this tendency to grammaticalize certain uses derived from voir/to see ${ }^{2}$ does not necessarily mean these uses will become part of an evidential system, as this grammaticalization is limited, for example, when voir is employed as an auxiliary to partially erase its visual aspect. Our working hypothesis is that in certain genres in French the evidential

\footnotetext{
${ }^{1}$ Note that the terms evidence and evidentiality are derived from the Latin word videre, meaning to see.

${ }^{2}$ See Chocheyras (1968) on this subject.
} 
characteristic of voir is usually expressed discursively. We postulate that is particularly true in the sciences, a genre that employs very specific forms in certain uses. As a result, we felt it would be interesting to examine differences in the discursive use of evidential markers in two fields: economics and linguistics. Finally, we wanted to show how difficult it is, in certain types of written discourse, to clearly differentiate between markers used to indicate visual sources, inferences or intellectual arguments based on statements made by other parties. After briefly explaining how voir functions in French and the framework for our study (part 1), we present the method used to analyze our corpus (part 2) and describe the two types of evidential usage of voir (parts 3 and 4). We conclude by contrasting the distribution of these two types of usage in the fields of economics and linguistics (part 5).

\section{Voir and the lexicon of perception in scientific genres \\ 1.1. Perceptual paradigm}

Voir is used in a wide variety of forms in scientific writings. Table 1 lists some of these lexical forms. The lexical field of voir can be divided into "subjective" verbs of perception (the agent is the subject and the object "seen" is the direct object) and "objective" verbs for which the subject is the object "seen" (see Whitt 2008). However, this field also contains other syntactic categories, such as adverbs or adverbial expressions (e.g. apparemment/apparently and à première vue/at first sight), prepositional forms (e.g. $a u$ vu de (ces résultats)/given (these results)), nouns (e.g. observation/observation, coup d'oeil/quick look) and adjectives (e.g. visible/visible, observable/observable).

Linguistic expressions within the lexical field of visual perception often have a hedge function, with certain verbs (e.g. apparaître/appear) and adverbials (e.g. visiblement/visibly, apparemment/apparently) being used by authors to dilute their responsibility (Nølke 1994). However, these verbs and adverbials can also have a direct evidential function (Dendale, 1994). As we will see below, this hedging role does not concern the verb voir or other expressions that have a more directly evidential function, such as $a u v u$ de/given and à la lumière de/in the light of. The role of these lexical elements is more to show that a "fact speaks for itself"; even if the access to this factual knowledge is rarely through purely visible perception.

We should also mention the fact that certain lexemes in the field of voir are used to contrast appearance and reality, or, more exactly, to contrast a spontaneous but erroneous visual analysis and a deeper analysis that is contrary to appearances. A première vue/at first sight and apparemment/apparently are often accompanied by an adjective such as surprenant/surprising, contre-intuitif/counter-intuitive or paradoxal/paradoxical, as in example (1). Here, the analysis favoured by the author is introduced by en fait/in $\mathrm{fact}^{3}$ :

(1) En revanche, l'influence du revenu du conjoint est conforme à celle qui ressort de travaux analogues, mais à première vue plus surprenante. On s'attendrait à ce qu'un revenu du conjoint plus élevé décourage l'activité du fait de la progressivité du système fiscal : les prélèvements sur un même salaire féminin sont d'autant plus élevés que le salaire du mari est conséquent, puisque la tranche marginale d'imposition est plus grande, ce qui n'est pas le cas sur le tableau 1. En fait le profil est perturbé par la forte homogamie sociale qui conduit les femmes diplômées à vivre avec des conjoints, eux aussi diplômés/On the other hand, the influence of the partner's revenue is similar to that found in other studies but, at first sight, more surprising. One would expect a higher partner revenue to discourage the activity because of the progressiveness of the tax system: the amount of tax paid on the wife's salary is higher when the husbands salary is high, because the marginal tax burden is larger, which is not the case in table 1 . In fact, the profile is skewed by the strength of social homogamy, which means that highly qualified women tend to live with highly qualified partners. (KIAP economics corpus)

\begin{tabular}{|c|c|c|c|c|c|}
\hline $\begin{array}{l}\text { "Subjective" } \\
\text { verbs }\end{array}$ & $\begin{array}{l}\text { "Objective" } \\
\text { verbs }\end{array}$ & Adverbs & Prepositions & Nouns & Adjectives \\
\hline voir/see & apparaître & visiblement/vi & au vu de (de & observation (les & visible/visible \\
\hline
\end{tabular}

3 For more on the use of en fait as an evidential marker, see Grossmann \& Wirth (2007). 


\begin{tabular}{|c|c|c|c|c|c|}
\hline $\begin{array}{ll}- & \text { observer/obse } \\
\text { - } & \text { rve } \\
\text { apercevoir } & \text { (s'apercevoir) } \\
\text { /perceive } \\
\text { - } \quad \text { regarder/look } \\
\text { (at) } \\
\text { discerner/det } \\
\text { ect } \\
\text { - examiner/exa } \\
\text { mine } \\
\text { repérer/recog } \\
\text { nize }\end{array}$ & $\begin{array}{l}\text { (la figure } \\
\text { apparaît } \\
\text {...)/appear } \\
\text { (the figure } \\
\text { appears... } \\
\text { - } \quad \text { sembler/see } \\
\text { m } \\
\text { - reveller/show } \\
\text { - dévoiler/reve } \\
\text { al } \\
\text { se } \\
\text { révèle/reveal } \\
\text { Adj }\end{array}$ & $\begin{array}{l}\text { sibly } \\
\text { - apparemment } \\
\text { /apparently } \\
\text { à première } \\
\text { vue/at first } \\
\text { sight } \\
\text { en } \\
\text { apparence/ap } \\
\text { parently }\end{array}$ & $\begin{array}{l}\text { ces } \\
\text { résultats, } \\
\text {...)/given } \\
\text { (these } \\
\text { results, etc) } \\
\text { à la lumière } \\
\text { de/in the } \\
\text { light of }\end{array}$ & $\begin{array}{l}\text { premières } \\
\text { observations } \\
\text { montrent que } \\
\text {...)(observation } \\
\text { (the first } \\
\text { observations } \\
\text { show) } \\
\text { coup } \\
\text { d'œil/glimpse }\end{array}$ & $\begin{array}{ll}\text { - } & \text { discernable/dis } \\
\text { cernable } \\
\text { - } \\
\text { apparent/appa } \\
\text { rent } \\
\text { observable/ob } \\
\text { servable }\end{array}$ \\
\hline
\end{tabular}

\section{Table 1: The lexical field of visual perception in scientific writings}

\section{2. Linguistic functioning of the verb voir}

In his Dictionnaire historique de la langue française, Alain Rey (2004: 4107) notes that the Latin verb videre, from which voir is derived, comes from the Indo-European root ${ }^{\circ}$ weid- which indicates vision, although primarily with respect to knowledge and only secondarily with respect to perception by sight. The Latin verb, like its French successor, whether it is used intransitively or with an accusative, signifies both perceived by sight, witness and notice ${ }^{4}$. This co-existence of the perceptive and intellectual meanings of voir is the source of its uses within the scientific genre and are the subject of the present study.

Numerous studies of the different uses of voir have been carried out, either as part of more general studies of verbs of perception, or separately (see in particular Bat-Zeev Shyldkrot, 1981, 1984, 1989, 1997, Picoche, 1986, 1993, Willems, 1983, 2000a, 2000b, François 2001, Franckel \& Lebaud, 1990, Labelle 1996, Naukkarinen, 1997, Leeman \& Sakhokia Giraud 2001, Grezka, 2006). These studies have used different theoretical frameworks to investigate the principles explaining the numerous uses of voir or the semantic variety of these uses. Franckel and Lebaud (1990), who applied Culioli's approach, showed the importance of the speaker's stance in interpreting voir, a point we feel is particularly important. Grezka (2006: 61), who took an object-class approach, highlighted the importance of the second argument for voir, as the first argument is always an animate NP.

Discussions have frequently looked at dichotomies, for example, between direct perception (= "physiological") and indirect perception (= "cognitive"), or between active perception (the perceptive act is controlled by the subject) and passive perception (perception is an experience that the subject undergoes) $)^{5}$. The roles of the co-text and of complements have been invoked to explain the passage from a passive meaning to an active meaning for prototypical "passive" verbs of perception, such as voir and entendre/hear. Grezka (2006:53) noted that the co-text may govern the selection of either a passive verb of perception (voir, entendre) or an active verb of perception (regarder/look, écouter/isten). For example, in order to specify an object that demands intellectual participation, an active form of voir is selected, as in As-tu vu un film hier soir/Did you watch a film yesterday evening? For many researchers, (e.g. Le Goffic (1993: 250), quoted in Grezca, 2006), when voir introduces a complement clause it takes on a more cognitive meaning and signals access to knowledge. This proposition is irrefutable, although it should be realized that in many cases the cognitive dimension of voir does not entirely override its perceptual dimension. In fact, access to a piece of information is often provided by a visual clue:

\footnotetext{
4 Leeman and Sakhokia Giraud (2001: 59) also highlight the intellectual and perceptive values of voir in French, linking them to etymology.

5 For a summary, see, in particular, Grezka (2006).
} 
(2) Mais en regagnant sa chambre, elle a vu que la porte du balcon était entrouverte/But, when she got back to her room she saw that the balcony door was ajar. (B. Friot, Histoires Pressées)

This example clearly shows that when voir acquires an evidential value (i.e. when it is used to indicate an observed fact), this always implies a double predicative dimension and therefore two processes: the process expressed by the subject of voir introduced by the observer and the process that translates the observed fact, which can be carried out syntactically in different ways. Without this double structure, voir would be a simple perceptual marker and would not have any evidential value. A sentence such as je vois un arbre/I see a tree appears to be a perceptual statement of fact and not a way of indicating the source or status of the information. This explains why, syntactically, the use of an evidential often involves either completive or infinitive propositions that can be regulated by voir, or other means of syntactically signalling a predication. The literature shows that an infinitive proposition favours a perceptual interpretation, whereas a completive construction leads to a more cognitive interpretation. This can be illustrated by contrasting the following two sentences:

(3) Je vois Paul partir vs Je vois que Paul part/I see Paul leave vs I see that Paul is leaving.

Both cases contain a double predicative structure: the structure associated with the observer who "sees", and the structure that corresponds to the observed fact, but the completive construction, which more strongly reinforces the two predications, seems to emphasize the observer's point of view. Hence, the completive construction appears to be a better candidate for use as an evidential marker. However, other structures can also be used. Thus, in a sentence such as:

(4) (...) On voit ici l'importance de R/We see here the importance of R. (Revue de statistique appliquée, 1962, vol. X, 1)

the evidential structure is expressed using an abstract predicative noun, rather than a completive. Our corpus study identified other syntactic constructions with evidential value in scientific writings.

\subsection{The framework used to study voir in scientific genres}

Although our study is based on the above facts, our approach was much more specific, as our aim was not to explain all the uses of voir, or its polysemy; rather, it was to examine the uses of voir in scientific writings and to try and identify criteria that can be used to identify the evidential role of these uses. We postulate that voir, when it forms part of an evidential structure in a scientific text, can be subject to three independent levels of analysis: lexical-semantic, enunciative and rhetoricalpragmatic.

Our lexical-semantic analysis used a similar approach to Fillmore's frame semantics. We believe that the evidential use of voir differs from other uses in the nature of the frame elements involved in the valence of voir. These roles can be identified through the syntactic constructions employed and through the semantic characterisation of the arguments of the verb ${ }^{6}$.

The enunciative level constitutes the polyphonic space in which the scientific demonstration occurs and indicates how the semantic frames are manifested in the enunciative interplay, most notably through the personal pronouns ${ }^{7}$. There is a complex relationship between the enunciative

\footnotetext{
${ }^{6}$ We present these roles at the end of the corpus analysis. In Fillmore's framework semantics, the predicative meaning is represented by prototypical situations or scenarios (frames), which can be divided into different levels of organization. These frames are seen as places of articulation between human experience and/or the cognitive dimension and the lexical coding. The semantic roles (or frame elements) correspond to the arguments of the predicates (verbal or nominal predicates). (Fillmore et al., 2003).

7 Fillmore (1982) identified two types of frame: cognitive frames and interactional frames. Interactional frames aim to represent the interaction between the locutor and the allocutor, or between the author and the reader. From this idea we have retained the need to bring together cognitive frames (and the elements associated with them) and the enunciative and textual perspective.
} 
interplay and the lexical semantic roles linked to the frame implied by the verb. As we will see with respect to voir, the figure of the scientific author ${ }^{8}$ is represented, in principle, by the personal pronouns Nous/We, On/One, and sometimes $\mathrm{Je} / \mathrm{I}$, which present the demonstration to a Model Reader. Although generally implicit, this Model Reader can appear in certain injunctive forms, for example, through the use of on (e.g. pour une synthèse, on se reportera à.../for a summary, see...).

Lastly, the rhetorical-pragmatic level takes into account how the lexical-semantic level is inserted into the text. We postulate that the evidential use of voir involves cognitive/rhetorical operations linked to scientific argumentation and that it frequently introduces a process of validation, thereby entering the proof system of the scientific genre. As Aikhenvald (2004) pointed out, there is no direct relationship between evidentiality and the proof or validation system. The act of specifying the source of a piece of information (evidential role) is not necessarily intended to guarantee the validity of that information. However, in certain genres of discourse, specifying the source represents a validating factor that is used argumentatively by the locutor. This is the case in scientific writing, which demands that the nature of the sources of information be specified whenever new information is added ${ }^{9}$. Specifying both the source of a piece of information and the way that information was obtained (personal work by the author, reference to work by peers) is an important element in validating research work.

\section{Methodology and corpus}

\subsection{The corpus}

Our study of voir was based on a corpus of scientific writings in French, taken from articles in respected journals, $\mathrm{PhD}$ theses, reports and course books, in two fields within the humanities: linguistics and economics. The journal articles were taken from the KIAP corpus, which was compiled by Kjersti Fløttum and his team (see Fløttum et al., 2006) for a detailed study of auctorial presence. The items from the KIAP corpus were supplemented by items from $\mathrm{PhD}$ theses, reports and course books.

Table 2 outlines the composition of the corpus, which contains just over 1.3 million words.

\begin{tabular}{||l|l|l||}
\hline & Linguistics & Economics \\
\hline $\begin{array}{l}\text { Scientific articles } \\
\text { (corpus KIAP) }\end{array}$ & 285881 words & 374516 words \\
\hline $\begin{array}{l}\text { Theses, reports, } \\
\text { course books }\end{array}$ & 364812 words & 286653 words \\
\hline Total & 650693 words & 661169 words \\
\hline
\end{tabular}

Table 2: Corpus of scientific writings used in the study of the verb voir

The corpus used was sufficiently large and varied for our purposes, which were to identify the main semantic and pragmatic functions of the verb voir, and to determine its syntactic characteristics.

\subsection{Productivity of the verb voir}

The verb voir is one of the most frequently occurring verbs in our corpus of scientific writings. As can be seen from Table 3, for economics and linguistics combined, voir is the ninth most frequently

\footnotetext{
8 In order to avoid any ambiguity, it must be remembered that the notion of author comprises several components: the author as an empirical being, the institutional author, as defined in law and, finally, the figure of the author as constructed at the enunciative and textual rhetoric levels. The latter is the component that interests us here.
}

${ }^{9}$ Chafe (1986) stressed the fact that certain well-established written genres have, over time, codified their use of very specific forms to mark evidentiality. 
used verb and the third "full" verb (after permettre/allow and considerer/consider), if auxiliary verbs, supporting verbs and modal verbs are excluded. In linguistics, it is the second "full" verb, whereas in economics it occupies fifth place, behind permettre/allow, considerer/consider, montrer/show and utiliser/use.

\begin{tabular}{|l|l|l|l|}
\hline Verb & Economics & Linguistics & Total \\
\hline être/be & 14709 & 15518 & 30227 \\
\hline avoir/have & 4494 & 4703 & 9197 \\
\hline pouvoir/be able to & 2557 & 3573 & 6130 \\
\hline faire/do or make & 783 & 1400 & 2183 \\
\hline permettre/allow & 1100 & 864 & 1964 \\
\hline devoir/have to & 732 & 638 & 1370 \\
\hline mettre/put & 608 & 680 & 1288 \\
\hline considerer/consider & 656 & 618 & 1274 \\
\hline voir/see & $\mathbf{5 1 9}$ & $\mathbf{7 3 4}$ & $\mathbf{1 2 5 3}$ \\
\hline montrer/show & 637 & 379 & 1016 \\
\hline apparaître/appear & 286 & 706 & 992 \\
\hline prendre/take & 426 & 556 & 982 \\
\hline donner/give & 426 & 536 & 962 \\
\hline \hline utiliser/use & 541 & 414 & 955 \\
\hline correspondre/correspond & 389 & 556 & 945 \\
\hline
\end{tabular}

Table 3: The most frequently occurring verbs in the corpus of scientific writings

Voir can therefore be considered representative of scientific writings. However, as we saw above, voir has a wide variety of uses that need to be described in more detail. The corpus was annotated for this purpose.

\subsection{Annotating the different uses of voir in the corpus}

As was noted in section 1, voir is a polysemic verb that is not easy to analyze and that has resisted even the best efforts to identify a common semantic core for all its different meanings (see Picoche 1986, 1993; Franckel \& Lebaud 1990). For the present study we adopted a pragmatic approach, as our main objective was to isolate the evidential uses of voir. This led us to identify the main senses, which represent only a subset of the uses described in reference works (for example, in the Petit Robert dictionary or in the Trésor de la Langue Française). As far as possible, we associated the main senses with precise argumental structures, in order to facilitate their analysis and to annotate them in the corpus.

Five main senses were identified in the corpus and the different occurrences of these senses in the corpus were labelled using XML annotation.

1. Voir as a statement marker (evidential)

Prototypical syntactic structure: NP (hum) voit (that Sentence) | NP (abs)

This use, which is very common in scientific writings, can be considered evidential. The origin of a fact, here introduced in the completive ('visage' a un fort degré d'affinité avec la majorité de ces cliques/'face' has a high degree of affinity with the majority of these cliques), becomes obvious to the author and the reader (on/one) through simple observation, often of a visual support (e.g. a table).

(5) On peut voir dans ce tableau que visage a un fort degré d'affinité avec la majorité de ces cliques/The table shows that 'face' has a high degree of affinity with the majority of these cliques. (Linguistics corpus). 
This sense is similar to the one described by Whitt (2008) as, 'an inference based on observation'. We have also used this label for slightly different senses, including the one labelled 'knowledge and understanding' by Whitt. In most cases, in a corpus, it is extremely difficult to separate these two uses $^{10}$.

2. Voir as a reference marker (evidential)

\section{Syntactic structure: Sentence (voir NP or voir Adv)}

Another important function of voir - which we believe is specific to scientific writings - is its use to indicate intratextual or intertextual references. In this context, voir, used in the infinitive, is often placed in parentheses and followed by one or more intra- or intertextual references. For example:

(6) Les auteurs qui traitent ... d'à travers et au travers de abordent systématiquement ces prépositions à partir de leurs emplois spatiaux, de nature intrinsèquement dynamique (voir par exemple, Borillo 1998: 85, Spang-Hanssen 1963: 231-233)/Authors who study... ... "à travers" and "au travers de" systematically approach these propositions from a spatial perspective, which is intrinsically dynamic (see, for example, Borillo 1998: 85, Spang-Hanssen 1963: 231-233) (Linguistics corpus).

(7) On vérifie, aisément, que la fonction valeur $V(x t-1, R t)$ est solution de l'équation de Bellman (voir annexe $E$ )/It is easy to check that the value function $\mathrm{V}(\mathrm{xt}-1, \mathrm{Rt}$ ) is the solution to the Bellman equation (see appendix E). (Economics corpus)

Section 3 presents a detailed analysis of how these two evidential values of voir function.

3. Voir in the sense of 'to examine' (non evidential)

Syntactic structure: NP (hum) voir NP (- hum)

This sense, which is quite common in scientific writings, is not an evidential use, as the following examples show:

(8) Voyons les sèmes que le contexte du programme des Verts nous permet d'extraire à propos de ces deux courants synchroniques dans nos pays industrialises/Let us look at the semantic structures that the context of the Green Party's program allows us to extract with respect to these two synchronous currents in our industrial countries. (Linguistics corpus)

(9) Notre objectif est maintenant de déterminer les prix d'équilibre. Nous allons procéder en deux temps. Nous verrons tout d'abord l'équilibre instantané/Our objective now is to determine equilibrium prices. We will do this in two stages. First we will look at the instantaneous equilibrium. (Economics corpus)

The element introduced by voir, an SN, is not a fact. It is often an object analyzed by the author during the demonstration or the study.

4. Voir as an opinion and judgement verb (non evidential)

Syntactic structures:

a. $\mathrm{NP}($ hum) voir $\mathrm{NP}(\mathrm{abs})$ as $\mathrm{NP}(\mathrm{abs})$

b. 2. NP(hum) voir NP(abs) PrepLoc NP(abs)

In these senses (see examples below), voir can be considered a verb of opinion or judgement, and it does not have an evidential use.

(10) Les cotisations du système par répartition sont souvent vues comme des prélèvements obligatoires sans contrepartie/Contributions paid into a redistribution system are often seen as obligatory deductions that do not give any return. (Economics corpus).

(11) ... l'on voit dans l'énonciation une sorte de prolongement du structuralisme .../we can see in the utterance a sort of extension of structuralism... (Linguistics corpus)

5. Other non-evidential uses

Other non-evidential uses were found in our corpus, but much less frequently. These include uses that are totally specific to the verb voir in its role as a semi-auxiliary of the passive, as in the following example:

\footnotetext{
${ }^{10}$ For example, both values are possible in the phrase on voit bien dans ce schéma que/this diagram clearly shows: recognition is combined with a deduction.
} 

"comme une activité qui modifie une situation en faisant reconnaître à autrui une intention pragmatique »/The theory of enunciative operations is intimately associated with a definition of language "as an activity that modifies a situation by acknowledging the pragmatic intention of a colocutor". (Linguistics corpus)

It is interesting to note that the corpus did not contain any examples of direct perceptual usage. Chafe (1986) recorded a similar finding for English.

\subsection{Distribution of the uses of voir in the corpus}

By identifying values and annotating the corpus it was possible to determine the most common uses of voir in our corpus. As Figure 1 shows, evidential uses account for an overwhelming majority of occurrences $(75 \%)$.

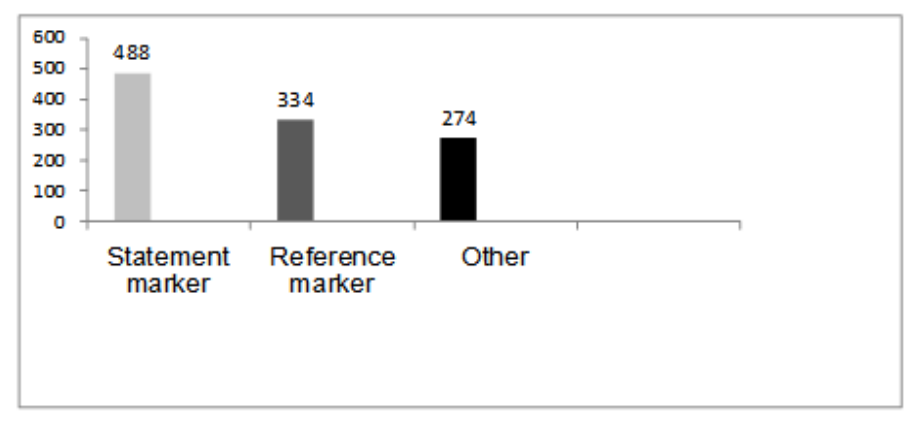

Figure 1: Distribution of the different uses of voir in the corpus of scientific writings (number of occurrences)

In addition, statement and reference markers show interesting syntactic and enunciative specificities that we will examine in the following two sections.

\section{Voir as a statement marker}

In these uses, the origin of the stated fact is not directly perceptual because the author is presenting a proposition. As in the perceptual sense, the syntactic subject can be considered non-active (the thematic role as a patient or an experiencer) as it receives the information, but does not really "create" it. Thus voir differs from verbs such as déduire/deduce or conclure/conclude, which bring into play more complex mental operations. However, in some examples, voir is not only constative; it also includes a notion of demonstration. This is notably the case when the verb is used in the present perfect tense, as in the following example:

(13) On a vu que couper correspond à des procès très différents dans ses différents emplois lexicaux /We have seen that, in its different lexical uses, to cut refers to very different processes. (Linguistics corpus)

It is difficult to unequivocally interpret this example out of context, but it is probable that the author has established this fact, rather than merely stating it in an earlier section of the text describing several lexical uses of the verb couper/to cut. The use of voir, rather than montrer/show or établir/establish, gives the text greater objectivity, in the true sense of the word: the facts are self evident and the responsibility of the author - which would appear greater if he/she had used terms such as on a montré/we have shown, or on a établi/we have established- is pushed to the background.

Moreover, in scientific writings, voir as a statement marker occurs in specific syntactic contexts and has specific enunciative properties. 


\subsection{The subject of voir as a statement marker: inclusion of the "reader as witness"}

The subject of voir is nearly always on/one or nous/we (90.5\% of occurrences in our corpus $\left.{ }^{11}\right)$, as in the following examples:

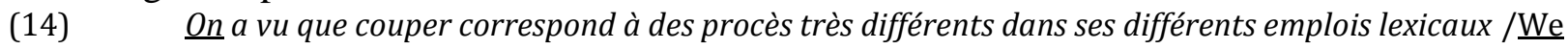
have seen that, in its different lexical uses, to cut corresponds to very different processes. (Linguistics corpus)

(15) Comme nous l'avons vu précédemment, la définition et le choix d'un concept pour l'équité posent de redoutables problèmes/As we saw earlier, the definition and the choice of a concept for equity is extremely problematical. (Economics corpus)

The personal pronouns nous and on are not used merely out of protocol. They cannot be replaced by a first person singular pronoun, as they can in the case of other verbs, such as montrer/show or démontrer/show:

1. *J'ai vu précédemment que couper correspond à des procès très différents .../I saw earlier that to cut corresponds to very different processes...

2. J'ai démontré/montré précédemment que couper correspond à des procès très différents .../I showed earlier that to cut corresponds to very different processes...

The fact that it is impossible to replace nous/on by je shows that the author is not the originator of the fact described (the $j e$ is not an active agent), but that the facts are, to a certain extent, selfevident. Furthermore, nous and on in these cases are not exclusive, as they include the community of peers, as in examples such as:

(16) On admet couramment en épistémologie qu'il n'existe pas de chose en soi que le scientifique pourrait appréhender sur le mode de l'observation pure/It is widely accepted in epistemology that there are no things in and of themselves that a scientist can understand through pure observation. (Economics corpus)

In fact, when nous and on are used with voir to form a statement marker, they are inclusive (I + YOU) in that they include the reader, who is called upon to witness, alongside the author, the facts described $^{12}$. Here, voir, like other verbs of the same paradigm, is clearly used in a dialogical context (as it is when it is used as a reference marker), where the author draws the reader's attention to a group of facts that support the author's reasoning. The inclusion of the reader in verbal forms is quite rare in scientific writings, with the exception of certain imperatives ${ }^{13}$, as indications that the reader is being taken into account generally take the form of markers that guide the reader, such as metatextual elements (d'une part/on the one hand, pour conclure/to conclude, etc).

\footnotetext{
${ }^{11}$ In most other cases, when voir is used as a statement marker, it is used in an impersonal form:
}

Il est surprenant de voir que ce type de compétence est également produit dans l'entreprise/It is surprising to see that this type of skill is also produced within the company. (Economics corpus)

Il s'agit aussi de voir comment notre modèle rend compte des différents facteurs de la polysémie adjectivale/It is also about seeing how our model explains the different factors of adjectival polysemy. (Linguistics corpus)

${ }^{12}$ In their study of the pronoun on/one in the KIAP corpus, Fløttum et al. (2006) also showed that the inclusive use of on is particularly linked to verbs of perception.

${ }^{13}$ The reader's attention can be solicited through the use of certain first person plural imperatives, as well as through pronominal and verbal forms (see Fløttum et al. 2006), as in the following examples:

Enfin, examinons une dernière donnée/Finally, let us look at one last piece of data. (Linguistics corpus)

Voyons brièvement quelques examples/Let us take a brief look at a few examples. (Linguistics corpus)

It is interesting to note here that the verbs in the examples also belong to the voir paradigm, even if they do not have an evidential function. 


\subsection{Voir as a parenthetical}

Another specific characteristic of voir as a statement marker is its use as a parenthetical (on l'a vu/we have seen, on le verra/we will see, comme nous le voyons/as we can see, etc), as in the following examples:

(17) Les métaphores vives, on l'a vu, sont sensibles au contexte, et il est nécessaire de connaître les conditions d'énonciation pour pouvoir attribuer un sens précis à l'énoncé./Living metaphors, as we have seen, are context dependent, and it is necessary to know the conditions of enunciation in order to be able to attribute a meaning to the utterance. (Linguistics corpus)

(18) Le facteur individuel incorpore en effet les orientations du couple en matière de descendance et, comme on l'a vu, celles-ci se traduisent probablement dans les choix du ménage en matière d'habitation ou de biens durables .../The individual factor incorporates the couple's choices in terms of having children and, as we have seen, these choices are probably reflected in their choices in terms of accommodation or consumer durables... (Economics corpus).

These uses account for more than $20 \%$ of the occurrences in our corpus, and seem to be characteristic of scientific writings. As Rooryck (2001) showed, parentheticals are used particularly frequently with verbs expressing evidentiality. On a communicative level, the secondary predication expressed by voir reinforces its evidential function: the author provides a reminder that the facts expressed by the primary predication are justified by an observation that is made in association with the reader. In addition, the use of parentheticals helps to maintain textual coherence and the complicity with the reader by announcing information to come or by recapitulating facts that have already been demonstrated and observed. These elements help guide the reader, alongside other intertextual marks that we will look at now.

\subsection{Supporting a statement: locative complements}

Although voir is not used as a verb of perception in scientific writings, the visual dimension is not completely absent. The author uses the text, sometimes supported by graphs and tables, to ask the reader to accept certain facts. Textual support may be implicit, in that it does not include any specific markers, but it is often given explicitly through intertextual locative complements, such as adverbs of place (ici/here, plus haut/above, ci-dessous/below, supra/above, infra/below, etc) or prepositional phrases that indicate tables, graphs or other parts of the text to be examined (dans la section 1/1n section 1, dans le tableau 2/1n table 2, etc). For example:

(19) On peut voir dans le tableau précédent que ce taux est dû essentiellement à la contribution des cliques .../The above table shows that this rate is mostly due to the contribution of the cliques... (Linguistics corpus)

(20) Comme nous l'avons vu dans le chapitre 2 , la proximité géographique relève de la localisation dans l'espace des acteurs et de leurs liens en termes de distance .../As we saw in chapter 2, geographical proximity decribes the localization of the parties in space and their links in terms of distance... (Economics corpus)

In a small number of cases the localization does not appear in a complementary clause, but in a parenthetical structure, which is a point of similarity between this use of voir and its use as a reference marker:

(21) Avant le XVIe siècle, on l'a vu (chapitre I, section 2.1.), le terme d'antonomase recouvre principalement l'antonomase $d u$ nom commun/Before the $16^{\text {th }}$ century, as we have seen (chapter I, section 2.1.), the term antonomasia mostly covered the antonomasia of the common noun...(Linguistics corpus)

Like parentheticals, intratextual locative markers improve textual coherence and allow the author to guide the reader through the demonstration. These elements help support the argument by indicating the place of observation.

\subsection{Summary}

In scientific writings, voir (and its paradigm) as a statement marker can be described using Fillmore's frames (2003). 
Voir brings into play the following frame elements:

- A witness

This element is generally realized using an inclusive subject pronoun (nous or on) that encompasses the author(s) and the readers.

- A fact:

Prototypically, the stated fact is expressed by a complement clause or an NP consisting of an abstract noun, but it can also appear in a principal in the case of parentheticals

- A localization:

Implicitly, the localization of the statement is the piece of scientific writing. Sometimes, the localization is expressed explicitly using an intratextual locative (section, chapter, figure, linguistic example).

The following table summarizes the different uses with different types of example.

\begin{tabular}{|l|l|l|l|}
\hline Examples & Witness & Fact & Localization \\
\hline $\begin{array}{l}\text { On voit ainsi sur la Figure 4 qu'un } \\
\text { changement de seuil peut faire basculer } \\
\text { une configuration d'ambiguité/ Thus, we } \\
\text { can see from Figure 4 that a change in } \\
\text { threshold can clarify an ambiguous } \\
\text { configuration }\end{array}$ & On/One & $\begin{array}{l}\text { un changement de } \\
\text { seuil peut faire } \\
\text { basculer une } \\
\text { configuration } \\
\text { d'ambiguité/ a } \\
\text { change in threshold } \\
\text { can clarify an } \\
\text { ambiguous } \\
\text { configuration }\end{array}$ & sur la Figure 4/ Figure 4 \\
\hline $\begin{array}{l}\text { Les métaphores vives, on l'a vu, sont } \\
\text { sensibles au contexte, .../Living } \\
\text { metaphors, as we have seen, are } \\
\text { dependent on context... }\end{array}$ & On/One & $\begin{array}{l}\text { Les métaphores vives } \\
\ldots \text { sont sensibles au } \\
\text { contexte,.../Living } \\
\text { metaphors..., are } \\
\text { dependent on } \\
\text { context... }\end{array}$ & $\begin{array}{l}\text { (not realized - the piece of } \\
\text { scientific writing by } \\
\text { default) }\end{array}$ \\
\hline
\end{tabular}

In the following section, we show that this structure can also be applied to the use of voir as a reference marker.

\section{Voir as a reference marker}

The second use of voir in scientific writings is as a reference marker ${ }^{14}$, an aspect that might seem out of place in a discussion of evidentiality. In fact, voir is commonly used in the infinitive as a synonym for $c f$ (Latin confer $=$ compare $)^{15}$ to direct the reader to a source. This use, which involves a double predication, differs from the typical evidential structure (described above) in appearance only. In fact, the second predication is expressed using an imperative form of voir, as the main predication corresponds to an assertion made in a locution or a section of the text to which the reference is made. This indicating function is closely linked to the use of the infinitive with an imperative value, but voir falls into a frame that is very similar to the one described in the section

\footnotetext{
${ }^{14}$ The Framenet project has catalogued the equivalent usage of see in English, using a frame called Source_of_information, which is defined as: "In a text, a Source_of_information is given that provides a reader of the text with further Information relevant to the text. In this frame the author and reader are completely deprofiled, with the Source_of_information made salient". Nevertheless, this deprofiling of the enunciative roles remains relative, as the role of the jussive infinitive can be interpreted as an invitation to the reader.

15 Although the two forms are often presented as equivalents (PhD students are generally advised to choose one of the two systems), semantic motivation, which is slightly different, can explain some nuances of usage. $\mathrm{C} f$. (abbreviation of the Latin confer/compare) can also be used to introduce other elements of the same order as those already introduced; whereas voir emphasizes more clearly the desire to document the source of an affirmation. In practice, however, the two markers are often used interchangeably.
} 
on voir as a statement marker. The reference introduced by voir provides the source and validates the text preceding voir. The reader is encouraged to check, to "go and see", the content of a source that supports the author's affirmation. The source can be external (intertextual use of voir) or internal (intratextual use). Peritextual content (footnotes) and parentheticals are important but slightly different means of introducing elements of proof into the reasoning. More detailed studies are needed to compare the uses of voir as a source indicator alongside other referencing modes. The introduction of the author-date system by scientific publications allows authors to refer to sources supporting affirmations by simply adding the relevant publication date in parentheses. However, this sometimes leads to difficulties in interpretation ${ }^{16}$, as the reference can be regarded either as a simple reference to an affirmation made by another author, or as an element that is considered to have been accepted by the scientific community. Similar ambiguities occur with the intertextual use of voir.

\subsection{Voir as an intertextual reference marker}

When applied intertextually, voir is most commonly used to refer to other work that supports an affirmation:

(22) L'accroissement des inégalités face à l'emploi constitue l'un des traits majeurs de l'évolution du marché du travail dans les années 80. La progression de l'écart relatif des niveaux de chômage des actifs qualifiés et non qualifiés est une caractéristique particulière de ce phénomène inégalitaire (voir par exemple, GLYN [1995])/The rise in inequalities with respect to employment is one of the main features of the evolution of the job market in recent years. The increase in the differences between the unemployment rates for qualified and unqualified workers is an important characteristic of this phenomenon of inequality (see, for example, GLYN [1995]) (Economics corpus)

Here the validation is based on the knowledge accumulated by the scientific community in a certain field. In most of its uses, voir is accompanied by modifiers (in the above example, the modifier is par exemple/for example) that reinforce the validity of the presented fact. For example, terms such as entre autres/among others or par exemple/for example indicate that the fact presented by the author is so well known to the peer community that it is unnecessary to give a detailed list of references. The adverbs notamment/notably and en particulier/in particular are used to emphasise the importance of a specific contribution by highlighting the author's expertise, which allows him/her to establish a hierarchy in the sources used.

Intertextual reference markers, which indicate sources of evidence, belong to a secondary enunciative level. Two localizations account for an overwhelming majority of occurrences: parentheticals (as for the use of voir as a statement marker) and, even more frequently, footnotes (Table 2), although, as we will see below, there is a substantial difference in their frequencies of use in economics and linguistics writings.

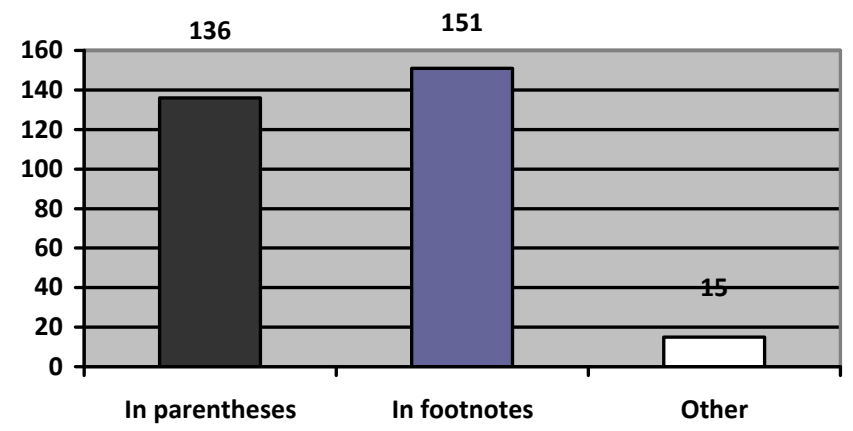

Figure 2: Occurrences of voir as a reference marker

A parenthetical statement marker using voir is placed immediately after the fact it supports. The sources given, which form the localization, affirm the stated fact. When voir is used in a footnote, it

${ }^{16}$ On this question, see Grossmann (2002). 
operates slightly differently. Like a parenthetical statement marker, a footnote number, placed at the end of the stated fact, may refer to a note providing an intertextual reference that supports the validity of the stated fact. However, some intertextual references introduced by voir also seem to have another, not entirely evidential function, in that they provide further information about a point that has not been sufficiently explained in the main text or they introduce complementary information, as in the following example.

$$
\text { (In the body of the text) }
$$

On ne saurait considérer comme relevant tout à fait du hasard le fait qu'à la fin du dix-neuvième siècle le philosophe Victor Egger consacre un livre à la parole intérieure, tandis que dans ses leçons sur l'aphasie Charcot met à l'ordre du jour la question du langage intérieur et que le roman contemporain promeut le monologue intérieur 1 /We would not consider it to be pure coincidence that at the end of the $19^{\text {th }}$ century the philosopher Victor Egger devoted an entire book to internal speech, while in his lectures on aphasia Charcot raised the question of internal language and contemporary novels promoted inner dialogue ${ }^{1}$.

(As a footnote)

1. Voir notamment à ce sujet la contribution de Christian Puech dans ce recueil/For more on this subject, see the contribution by Christian Puech in this volume.

(Linguistics corpus)

Parenthetical reference markers can also be used in this way, but this is much rarer.

\subsection{Voir as an intratextual reference marker}

When used intratextually, voir refers the reader to another part of the text, as in the following examples:

(24) Cette distinction reprend deux des fonctions (excellence et circonstances, mais pas filiation) de l'antonomase antique (voir 1.2.1.)/This distinction takes into account two of the functions (excellence and circumstances, but not parentage) of ancient antonomasia (see 1.2.1) (Economics corpus)

Here, the locative source is the complement of voir. This obligatory complement is sometimes realised by a locative adverb that guides movement through the text (ci-dessous/below, cidessus/above, infra/below, supra/above ${ }^{17}$ ), as in the example above, or by a simple paragraph, section or part number. Unlike intertextual uses, the inclusion of voir (or $c f$.) is obligatory. Locative complements are comparable to those that appear with statement markers and, in general, these two uses appear very similar in all aspects other than their syntactic structures. Hence, the following statement marker can easily be transformed into a reference marker by making a few adjustments to the syntax.

(25) Use as a statement marker (original example)

Nous avons déjà vu à la fin de la Section 2 que l'interdiction de pratiquer la discrimination du troisième degré entre marchés à élasticités différentes a des conséquences ambiguës sur le bien-être/We have already seen at the end of Section 2 that the ban on carrying out third degree discrimination between markets with different degrees of elasticity has ambiguous consequences on well being.

(26) Use as an intratextual reference marker (Manufactured example)

L'interdiction de pratiquer la discrimination du troisième degré entre marchés à élasticités différentes a des conséquences ambiguës sur le bien-être (voir la fin de la Section 2)/The ban on carrying out third degree discrimination between markets with different degrees of elasticity has ambiguous consequences on well being (see end of Section 2)

\footnotetext{
17 We did not find passim (çà et là/here and there) in the corpus, which allows us, according to the TLFI, "to avoid mentioning the exact localization of passages with a bearing on a given subject when a reference is given".
} 
When used as an intratextual marker, voir is often placed in parentheses but it is relatively rare for it to be used with footnotes, at least in economics texts. References to appendices containing documentary sources are also common:

(27) (...) On vérifie, aisément, que la fonction valeur $V(x t-1, R t)$ est solution de l'équation de Bellman (voir annexe E)/It is easy to check that the value function $\mathrm{V}(\mathrm{xt}-1, \mathrm{Rt})$ is a solution for the Bellman equation (see appendix E). (Economics)

Intratextual references can also be more complex, as in the case of syntactic units such as voir notre développement précédent sur.../see our previous discussion of... where the indicator refers to ideas developed in those sections of the text as well as to a localization.

\subsection{Summary}

To conclude, most uses of voir as a reference marker are cognitively and rhetorically similar to its uses as a statement marker, hence, their structures can be described using the same frame:

- The witness (the reader), who is asked to check the validity of sources, is expressed dialogically by the use of the imperative infinitive.

- The fact is the statement preceding the reference indicated by voir.

- The localization is the intra- or intertextual object introduced by the marker voir. In this case, voir is obligatory, contrary to statement markers.

The following examples illustrate this structure.

\begin{tabular}{|c|c|c|c|}
\hline Examples & Witness & Fact & Localization \\
\hline $\begin{array}{l}\text { (...) On vérifie, aisément, que la fonction } \\
\text { valeur V(xt-1, Rt) est solution de l'équation } \\
\text { de Bellman (voir annexe E)/It is easy to } \\
\text { check that the value function } \mathrm{V}(\mathrm{xt}-1, \mathrm{Rt}) \text { is } \\
\text { a solution for the Bellman equation (see } \\
\text { appendix } \mathrm{E}) \text {. (Economics) }\end{array}$ & $\begin{array}{l}\text { (the receiver, } \\
\text { who appears } \\
\text { implicitly in } \\
\text { the infinitive } \\
\text { imperative } \\
\text { form) }\end{array}$ & $\begin{array}{l}\text { On vérifie, aisément, que la fonction } \\
\text { valeur V(xt-1, Rt) est solution de } \\
\text { l'équation de Bellman/ It is easy to } \\
\text { check that the value function V(xt-1, } \\
\mathrm{Rt}) \text { is a solution for the Bellman } \\
\text { equation }\end{array}$ & Appendix E \\
\hline $\begin{array}{l}\text { La progression de l'écart relatif des } \\
\text { niveaux de chômage des actifs qualifiés et } \\
\text { non qualifiés est une caractéristique } \\
\text { particulière de ce phénomène inégalitaire } \\
\text { (voir, par exemple, GLYN [1995])/The } \\
\text { increase in the differences between the } \\
\text { unemployment rates for qualified and } \\
\text { unqualified workers is an important } \\
\text { characteristic of this phenomenon of } \\
\text { inequality (see, for example, GLYN } \\
[1995])\end{array}$ & As above & $\begin{array}{l}\text { La progression de l'écart relatif des } \\
\text { niveaux de chômage des actifs } \\
\text { qualifiés et non qualifiés est une } \\
\text { caractéristique particulière de ce } \\
\text { phénomène inégalitairel The increase } \\
\text { in the differences between the } \\
\text { unemployment rates for qualified and } \\
\text { unqualified workers is an important } \\
\text { characteristic of this phenomenon of } \\
\text { inequality }\end{array}$ & GLYN [1995] \\
\hline
\end{tabular}

\section{Comparison between economics and linguistics}

One of our working hypotheses was that the evidential function in our corpus involves cognitive operations that are related to scientific reasoning and textual rhetoric. As methods, types of scientific object examined and modes of reasoning differ between fields, we hypothesized that the evidential use of voir would also vary according to the field.

Detailed examination of our corpora confirmed this hypothesis. First, voir occurred more frequently in our linguistics corpus (513 occ.) than in our economics corpus (420 occ.), for similar-sized corpora. Two main differences in the distributions of the uses of voir were also noted (see Figure 3). 


\section{5}

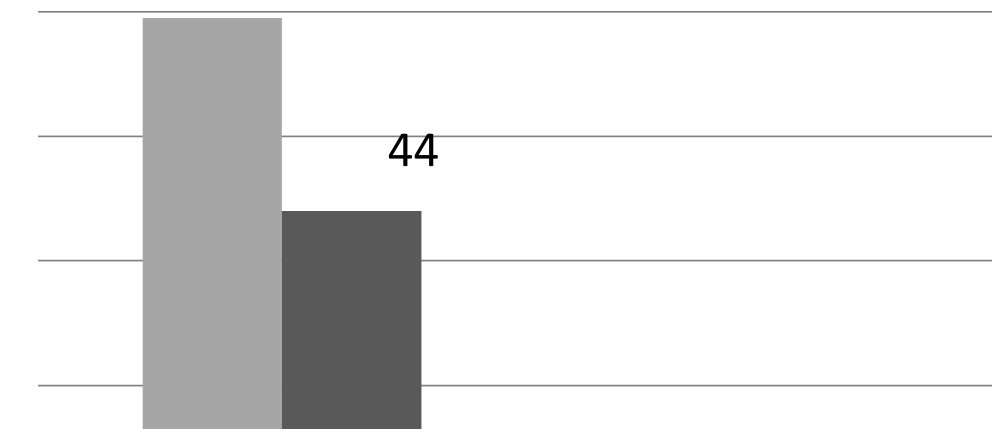

Figure 3: Evidential uses of voir in economics and in linguistics (in \%)

Linguistics texts contain more statement markers, whereas economics texts contain more intertextual references. However, comparable numbers of intratextual markers are found in the two fields.

These results can be interpreted in a number of ways. The greater use of statement markers by linguists may be the result of a greater need to involve the reader in the demonstration. However, this hypothesis does not seem to be supported by the occurrence of the other markers of interaction with the reader that were identified by Fløttum et al. (2006) in the KIAP corpus ${ }^{18}$. For example, metatextual markers and imperatives occurred much more frequently in the economics corpus than in the linguistics corpus. Less importantly, the frequent use of statement markers by linguists probably results from the fact that linguistics authors often support their reasoning with examples in the text, whereas observations in economics are often based on linguistic objects, in particular numerical results.

The greater use of intertextual reference markers in economics writings suggests that economists are more likely to refer to previously established knowledge in their field, whereas linguists tend to base their statements on observations contained within their own text. It would be tempting to think that economists have a more cumulative concept of science and a greater tendency to build on the work of their peers. However, the bibliographies of economics articles tend to be shorter than those of linguistics texts, at least in the case of research articles (see Flottum et al. 2006: 219). Furthermore, the use of reference markers appears to be slightly different in the two fields: linguists favour parentheticals (60\% of occurrences), whereas economists tend to use footnotes $(66.5 \%)$, which often have other functions that are not purely evidential. From an academic point of view, economists may have a greater need to found their work on previous research carried out within their discourse community. This hypothesis is corroborated by a study carried out on information source markers, which are much more explicit in economics than in linguistics (Garcia 2008). Nevertheless, in order to avoid hasty judgments and caricatural sociological interpretations, a more detailed and qualitative analysis is needed to confirm these hypotheses.

Finally, although both fields appear to use comparable numbers of intratextual markers, they generally refer to different types of object. Most of the markers used in economics articles refer to graphs and tables summarizing data (figure 1, table 2, graph 1), or to other sections of the text, either specifically (section 1, appendix D, note 4) or generally, using "vague" adverbs of place (supra/above, infra/below, plus haut/above, ci-dessous/below, etc). In linguistics, references to tables and graphs are rare, as linguistics articles do not tend to contain such elements. On the other

\footnotetext{
18 NB: our corpus contains the French economics and linguistics articles from the KIAP corpus.
} 
hand, linguistics articles do contain references to examples within the text, although $c f$. is more commonly used in these cases.

\section{Conclusion}

The verb voir, analyzed here within a subset of scientific writings, is only one element, albeit a very productive one, in the evidential system used in this discursive genre. Hence, it would be valuable to integrate studies of voir, and of verbs such as observer/observe, s'apercevoir/notice and examiner/examine into more general studies of the evidential role of markers referring to visual metaphors. Analysis of our corpus has revealed a recurring semantic structure (frame) containing three main elements: a witness, a fact and a localization. However, this structure also includes a certain amount of diversity, which can be described using three main criteria:

a) The degree of syntactic and semantic integration between voir and the stated fact. Integration is strong in completive structures indicating an observation (on a vu que/we have seen that, etc.). In parentheticals the degree of integration is lower. There is also a third level, where voir appears in a separated structure within parentheses, in which the degree of integration is even lower. The syntactic and scriptural distance from the fact is even greater when voir is used peritextually, for example, in a footnote ${ }^{19}$;

b) The type of localization: implicit or explicit, intratextual or intertextual. Implicit localizations (i.e., not referring to a precise location within the same text or in a precisely identified external source) and parentheticals without explicit localizations often reinforce the rhetorical or cohesive function. Localizations are always intratextual in the case of voir as a statement marker (On voit dans Duchmoll 2003 que...At can be seen from Duchmoll 2003 that...). In the case of voir as a reference marker, a localization must be given, as the localization associated with voir is an essential complement and not a modifier;

c) The status of the witness, who may have a different role in scientific reasoning. The witness is first a Being in discourse, who is associated with the co-observation of the facts presented. Here, the dialogical dimension is central and aims to involve the reader in the demonstration. Thus, the reader is called upon to witness, either through a statement with which he/she is associated by the inclusive personal pronoun nous, or through an explicit invitation (using the imperative infinitive). In this second function - apparently more modest but nevertheless fundamental - the witness seems to be a mere guarantor of the information given.

So what is the exact status, in evidential terms, of the verb voir? Our data support the idea of a very strong ambivalence between the verb's perceptual meaning, which although secondary remains present, and its cognitive meaning, through which it indicates the inference. In examples such as en se reportant à la figure $3 b$, on voit que l'espace des phases est défini par deux variables/looking at figure $3 \mathrm{~b}$, we can see that the phase space is defined by two variables, Naukkarinen (1997: 123) voir is used as an inference marker. When used as an intratextual marker (as well as in numerous statement uses) voir allows an author to validate a statement by inviting the reader to look at data included in other parts of the text, thereby directing the "textual circulation. When used as an intertextual reference marker, voir directs the reader to supporting evidence provided by the writings of third parties, and thus indicates that the 'proof' is accepted by the relevant discourse community. In both uses, the reasoning role is inextricably entwined with the evidential function. Finally, our comparison between the fields of economics and linguistics supports our hypothesis that the traditions governing the use of evidential markers in scientific writings differ between fields, even for fields within the Humanities.

\footnotetext{
19 Of course, this does not prevent the information provided in a footnote from being capital, as, according to tradition, the text provides the arguments but the footnote provides the proof by giving the sources and a commentary that makes the text clearer. For a history of footnotes, see Grafton (1997).
} 


\section{Bibliography}

Aikhenwald, A. (2004): Evidentiality, Oxford/ New York, Oxford University Press.

Bat-Zeev Shyldkrot, H. (1981): A propos de la forme passive se voir +Vinf, Folia linguistica XV, 3-4: 387-407.

Bat-Zeev Shyldkrot, H. (1984): La concurrence entre la proposition conjonctive et voir + proposition infinitive, The

French Rewiew, LVIII/2 : 202-215.

Bat-Zeev Shyldkrot, H. (1989): «Les verbes de perception: étude sémantique», In Actes du XVIIème Congrès

International de Linguistique et Philologie Romanes, 1986, Tome 4, Université de Trèves, Tübingen: Max Niemeyer

Verlag, 282-294.

Bat-Zeev Shyldkrot, H. (1997): La grammaticalisation des auxiliaires; le cas de voir, Scolia, 10:205-224.

Chafe, W. (1986): Evidentiality in English conversation and academic writing. In Evidentiality: the Linguistic Coding of Epistemology, edited by Wallace Chafe and Johanna Nichols, 261-272. Norwood-New Jersey: Ablex Publishing Corporation.

Chafe, W. and Nichols, J. eds. (1986): Evidentiality: The linguistic Coding of Epistemology, Advances in Discourse Processes Vol. XX. Norwood-New Jersey: Ablex Publishing Corporation.

Chocheyras, J. (1968): Un nouvel outil grammatical en français moderne: le verbe voir, Le Français Moderne, 36/3.

Dendale, P. et Tamsmowski, L., eds. (1994): Les sources du savoir et leurs marques linguistiques, Langue Française 102.

Dendale, P. (1994): Devoir épistémique, marqueur modal ou évidentiel? Langue Française 102, 24-40.

Fillmore, Charles J. (1982): Frame semantics. In Linguistics in the Morning Calm, Seoul, Hanshin Publishing Co., 111137.

Fillmore, C., Johnson, C. \& Petruck, M. (2003): Background to FrameNet. In Fontenelle, Th. (ed.) Special Issue of the International Journal of Lexicography on FrameNet and Frame Semantics. Oxford, Oxford University Press, 235250 .

Fillmore, Charles J. (1985): Frames and the semantics of understanding. In Quaderni di Semantica, Vol. 6.2: 222-254.

Fillmore, Charles J. and B. T. S. Atkins (1992): Towards a frame-based organization of the lexicon: The semantics of RIK and its neighbors. In Lehrer, A and E. Kittay (Eds.) Frames, Fields, and Contrast: New Essays in Semantics and Lexical Organization. Hillsdale: Lawrence Erlbaum Associates, 75-102.

Fløttum, K., T. Dahl \& T. Kinn (2006): Academic Voices - across languages and disciplines. Amsterdam/Philadelphia: John Benjamins.

Franckel, J.-J. and Lebaud, D. (1990): Les figures du sujet, A propos des verbes de perception, sentiment, connaissance, Paris, Ophrys.

Garcia da Silva, P. (2008): Etudes des marques de la filiation dans les écrits scientifiques, Mémoire de master, Université Stendhal, Grenoble 3.

Grafton, A. (1997):The Footnote: A Curious History, Cambridge, MA: Harvard University Press.

Grezka, A. (2006): Etude du lexique de la perception : bilan et perspectives, Linguistics (Suvremena lingvistika), 61 / 2006, pages: 45-67, on www.ceeol.com.

Grossmann, F. (2002): Les modes de référence à autrui : l'exemple de la revue 'Langages', Faits de langue, 19, 255262.

Grossmann, F. \& Wirth, F. (2007): Marking Evidentiality in Scientific Papers: The Case of Expectation Markers, in K.

Fløttum (ed), Language and Discipline Perspectives on Academic Discourse, Cambridge Scholars Publishing,

Newcastle, UK, 202-218.

Kronning, H. (2003): Modalité et évidentialité. In Birkelund, M., G. Boysen \& P. Kjærsgaard (éds.) : Aspects de la modalité, Tübingen : Niemeyer, 131-152.

Labelle, M. (1996): Remarques sur les verbes de perception et la sous catégorisation, Recherches linguistiques de Vincennes, 25, 83-106.

Leeman, D. and Sakhokia Giraud, M. (2001): Point de vue culiolien sur le verbe voir dans Les Verbes français, Langue française, 153, 58-73.

Le Goffic, P. (1993): Grammaire de la phrase française, Paris, Hachette.

Lemhagen, G. (1979): La concurrence entre l'ínfinitif et la subordonnée complétive introduite par que en français contemporain, I. Introduction, Uppsala, Diss.

Miller, P. and Lowrey, B. (2003): La complémentation des verbes de perception en anglais et en français. In Philip Miller et Anne Zribi-Hertz (eds), Essais sur la grammaire comparée du français et de l'anglais, 131-188, Paris : Presses Universitaires de Vincennes.

Naukkarinen, O. (1997): Etude de quelques verbes de perception du français, Helsinki, Yliopistopaino.

Nølke H. (1994): La dilution linguistique des responsabilité. Essai de description linguistique des marqueurs évidentiels il semble que et il paraît que, Langue française, 102, 84-94.

Picoche, J. (1986): Structures sémantiques du lexique français, Paris, Nathan.

Picoche, J. (1993): Didactique du vocabulaire français, Paris, Nathan.

Rey, A. (2004): Dictionnaire historique de la langue française, Paris, Dictionnaires LE ROBERT. (Ed. or. 1992). 
Rooryk, J. (2001): Evidentiality. Part 1. Glot International Vol. 5, April 2001 ; No. 4, 125-133.

Whitt J. (2008). Evidentiality, polysemy, and perception verbs: a corpus-based analysis of English and German). Handout of the conference "The linguistic realization of evidentiality in European Languages", Bamberg, 27-28 february 2008. 